\title{
MYSM1 Gene
}

National Cancer Institute

\section{Source}

National Cancer Institute. MYSM1 Gene. NCI Thesaurus. Code C113233.

This gene is involved in both the deubiquitination of histone $2 \mathrm{~A}$ and transcriptional regulation. 